2 Peterson PA, Berggard I. Urinary immunoglobulin components in normal, tubular and glomerular proteinuria: quantities and characteristics of free light chains, IgG, IgA and Fcy fragments. Eur 7 Clin Invest $1971: 1: 255-64$

${ }^{3}$ Balsløv JT, Brun C, Jensen KB, et al. Cytostatic treatment of glomerular diseases. Effect of azathioprine on serum and urine proteins. Report from a Copenhagen study group of renal diseases. Acta Med Scand $1973 ; 193: 493-8$

4 Kistner S, Norberg R. Urinary excretion of serum proteins in renal disease. Studies of electrophoretic fractions and $\operatorname{IgA}, \operatorname{IgG}$ and $\operatorname{Ig} M$. Acta Med Scand 1970;187:55-60.

(Accepted 13 May 1981)

Departments of Medicine and Pathology, University of Newcastle upon Tyne NE1 4LP

H U RASHID, MB, FCPS, research fellow

C K BISWAS, Mr, MRCP, regional research fellow

A R MORLEY, MD, MRCPATH, consultant pathologis

D N S KERR, MSC, FRCP, professor of medicine

\section{Adoption of Glasgow Coma Scale in the British Isles}

One million head-injured patients attend British hospitals each year. Deciding who to admit and who to refer for specialised management depends on a reliable means of estimating conscious level-that is, an index of both the initial severity of injury and, if this changes, the development of intracranial complications. The Glasgow Coma Scale is a reliable and practical method of assessing conscious level in terms of three independently measured features-namely, eye opening, motor response, and verbal response. ${ }^{1}$ It has been widely recommended ${ }^{2}$ and adopted in many parts of the world as a guide to the management of patients with various forms of acute brain damage. Little information exists, however, on how widely the scale has been adopted by the two different kinds of unit-primary surgical units and neurosurgical units-that care for head injuries in Britain or about the factors that led to its adoption.

\section{Methods and results}

We sought information from all 31 Scottish hospitals that treat at least 10 head-injured patients a week and admit patients to their own wards for observation ${ }^{3}$ and requested similar data from the 42 neurosurgical units in the British Isles other than our own. We asked each unit about the method used to assess conscious level, its origin, and the reasons for its adoption and requested a specimen of the head-injury observation chart in local use

Methods used to assess head-injured patients in neurosurgical units in British Isles and Scottish primary surgical hospitals

\begin{tabular}{llllccc}
\hline & & & & $\begin{array}{c}\text { Glasgow } \\
\text { Coma } \\
\text { Scale }\end{array}$ & $\begin{array}{c}\text { Other } \\
\text { graded } \\
\text { systems }\end{array}$ & $\begin{array}{c}\text { Entries } \\
\text { in case } \\
\text { notes }\end{array}$ \\
\hline $\begin{array}{l}\text { Neurosurgical units } \\
\text { Scottish hospitals* served by neurosurgeons } \\
\text { who use: }\end{array}$ & $\ldots$ & 21 & 9 & 10 \\
$\begin{array}{l}\text { Glasgow Coma Scale.. } \\
\text { Another method }\end{array}$ & $\ldots$ & $\ldots$ & $\ldots$ & 21 & & \\
\end{tabular}

*Two regional neurosurgical units used Glasgow Coma Scale and two another method

Two-thirds of British neurosurgical units with a formal grading system used the Glasgow Coma Scale (table); no two of the nine other units used the same system. Of the six primary Scottish hospitals that used an alternative system, only two used the same one. Only where the regional neurosurgeons used the Glasgow system did the primary hospitals do so.

\section{Comment}

The adoption of the Glasgow Coma Scale by primary surgical and neurosurgical units is continuing. No alternative method is in common use, and no hospital that has introduced the Glasgow scale has later replaced it by an alternative system. Half the neurosurgical units in the British Isles have adopted the Glasgow Coma Scale, in response either to personal recommendation by other neurosurgeons or to the publicity that the scale has received at meetings in the medical ${ }^{4}$ and nursing press. ${ }^{5}$ No geographical pattern is discernible-for example, seven of the units in London use the scale but the five others do not; two units in Scotland use it and two do not.

By contrast, Scottish primary hospitals are influenced by the practice of the regional neurosurgical unit; where the neurosurgeons use the Glasgow scale the primary hospitals tend to follow their example. This reflects partly the direct influence of the neurosurgeons but also the stimulus of the relatively mobile population of junior hospital doctors and nurses, who carry word of the scale from hospital to hospital. Several units commented on the improved communication about patients after the adoption of the scale.

Where the regional neurosurgical unit did not use the Glasgow Coma Scale the Scottish primary surgical hospitals had no uniform method of recording conscious level; we even found different systems in different departments of the same hospital. If this pattern of practice is typical of that in Britain as a whole then many thousands of acutely brain-damaged patients are being assessed by a potentially bewildering range of techniques. The danger is that communication about a patient's state may be faulty, particularly when primary physicians and surgeons have to discuss management with neurosurgeons on the telephone. Hospitals would do well to review their practice with a view to agreeing on the use of a common system, in collaboration with their regional neurosurgeons.

1 Teasdale G, Jennett B. Assessment of impaired consciousness and coma Lancet $1974 ;$ ii $: 81-4$

2 Langfitt TW. Measuring the outcome from head injuries. $f$ Neurosurg $1978 ; 48: 673-8$

3 Strang I, MacMillan R, Jennett B. Head injuries in accident and emergency departments at Scottish hospitals. Injury 1978;10:154-9.

4 Harrison MJG. Coma. In: Hughes RAC, Matthews B, eds. Medicine. 3rd series. Oxford: Medical Education International, 1978:1649-51.

5 Teasdale G, Galbraith S, Clarke K. Acute impairment of brain function. 2. Observation record chart. Nursing Times 1975;71:972-3.

(Accepted 19 May 1981)

Department of Neurosurgery, Institute of Neurological Sciences,

Southern General Hospital, Glasgow G51 4TF

D GENTLEMAN, BSC, $\mathrm{MB}$, senior house officer

G TEASDALE, MRCP, FRCSED, reader

\section{Spread of Clostridium difficile among patients receiving non-absorbable antibiotics for gut decontamination}

Although the pathogenic role of Clostridium difficile in pseudomembranous colitis is well established, ${ }^{1}$ the epidemiology of infection with this organism is still poorly understood. Reports of clustering of cases of pseudomembranous colitis ${ }^{2}{ }^{3}$ suggest, however, that $\mathrm{Cl}$ difficile is readily transmissible among hospital patients.

We report on the spread of this organism among children receiving oral non-absorbable antibiotics to suppress their commensal bowel flora in preparation for bone marrow transplantation or during chemotherapy for acute leukaemia. The large numbei of antibiotics prescribed and the occasional occurrence of symptoms resembling those of pseudomembranous colitis prompted us to screen for $\mathrm{Cl}$ difficile in this group.

\section{Patients, methods, and results}

The transplant unit is comprised of cubicles permitting strict protective isolation and an adjacent open ward containing both patients convalescing after transplants and general medical patients. Those undergoing antibiotic gut decontamination received neomycin sulphate $20 \mathrm{mg} / \mathrm{kg} / \mathrm{day}$, colistin sulphate 40000 units $/ \mathrm{kg} /$ day, and amphotericin $15 \mathrm{mg} / \mathrm{kg} /$ day. After admission a weekly bacteriological screen, which included culture of stools, was performed to monitor the patients' bacterial flora. Stools were cultured on $7 \%$ horse-blood agar and MacConkey agar (Oxoid) aerobically; anaerobic cultures were performed on kanamycin blood agar and on cycloserine 